\title{
Pragmatic Markers of Voices in Femi Osofisan's Esu and the Vagabond Minstrels
}

\author{
Ade Adeniji ${ }^{*}$, Sade Olagunju \\ English Unit, Department of General Studies, Ladoke Akintola University of Technology, Nigeria
}

Copyright $\bigcirc 2018$ by authors, all rights reserved. Authors agree that this article remains permanently open access under the terms of the Creative Commons Attribution License 4.0 International License

\begin{abstract}
Pragmatic markers of voices are significant given the roles they play in the building and construction of utterances in culture-based texts. They reveal owners of voices thus enabling us to determine authorial preoccupations in literary texts. However, as significant as they are to the determination of voices and authorial perspectives, they have received little attention in linguistic scholarship. Employing the literary pragmatic theory therefore, this study sets out to examine how to detect voice ownership as indicated by pragmatic markers of voices such as references, deixis, pronouns, tenses and related authorial perspectives in Osofisan's Esu and the Vagabond Minstrels (EATVM), so selected, given that it is rich in data. The study reveals that Osofisan employs the pragmatic markers of voices such as references, deixis, personal pronouns, tenses and so on through his and his characters' voices, voice mash, voice trash, and voice crash, relative to issues of social power, moral and religious deviances, and religious beliefs, in EATVM. The study concludes that a study of pragmatic markers of voices enhances an understanding of voice ownership in literary texts towards determining authorial perspectives in post-colonial African conjured textual universes.
\end{abstract}

Keywords Pragmatic Markers, Culture-based Texts, Voice Ownership, Literary Pragmatic Theory

\section{Introduction}

A means to project a writer's worldview is the voice. According to Mey (2000:162), the notion of voice is central in determining voice ownership in literary texts. As significant as voice is in textual production, except for (Mey, 2000, 2001; Adeniji, 2009, 2014a, b) it has gained little attention from scholars in linguistic scholarship. This study therefore, sets out to examine how playwrights project their perspectives in drama texts through voicing. Our choice of drama text as creative medium is largely due to its ability to offer a corpus of materials for language study in the written mode. Also it is a medium for a writer to project his point of view about the society. Moreover, drama seeks to apprehend the truth of the universe and capture the decisive face of social development in an immediate, spontaneous, and effective manner.

The drama text chosen in this instance is that of Femi Osofisan. Osofisan is a Nigerian playwright, actor, director and songwriter whose plays are widely read and performed both in Nigeria and overseas. Notably, some of Osofisan's works have largely been associated with Marxism (see Obafemi, 1996, Awodiya 1995, Richards, 1996, Dasylva 2004), because of the themes of struggle and revolution in them. However, Egbarevba (2000) among others opines that Osofisan also projects non-political (or non-Marxist) issues such as hatred, peace, love, pride, patriotism and upliftment of Africa's myths, legends and folktales, which are projected in his texts through voicing.

Osofisan usually vocalizes his perspectives through his narrators, thereby trashing, mashing or crashing into the vocalization of his characters. It is useful therefore to examine how Osofisan employs the various voices so as to be able to appropriately determine his perspectives and specific intentions, especially, in his Esu and the Vagabond Minstrels (EATVM). The study is expected to enhance an understanding of Osofisan's voice tactics and perspectives in his plays. It will therefore enhance the interpretation of Osofisan's works as well as complement existing studies on the works of Osofisan in linguistic scholarship.

\section{Femi Osofisan}

Osofisan wrote over 26 published plays from 1969 to 2005. Winner of the first association of Nigerian Authors drama prize in 1983, Osofisan is a man of many parts; a renowned critic, poet, novelist, playwright, an actor and a producer. Osofisan's commitment to the negritude writers' course to reject Western ideologies that exploit Africa coloured his vision as his early plays dramatized his 
commitment to the theme of revolution, which tagged him a Marxist writer.

The visions projected in Osofisan's early writings are materials of his growing experience, having witnessed the exploitation of the colonial masters, the euphoria of independence and the subsequent disillusionment occasioned by the insensitive African leadership after independence (see Fatoba, 1988: Awodiya 1993: Richards, 1996 and others). Osofisan believes that drama can be used as an effective weapon for social change. Egbarevba (2000) observes that Osofisan's works portray a consciousness and commitment to societal development, which reflect in his choice and interpretation of materials. He submits that the totality of Osofisan's works portrays a humanistic perspective reflecting the societal structure built for the masses. His thematic focus has been that man is the machinery or oppression in the society he creates, and that man is also capable of dislodging it.

However, Egbarevba (2000) notes that Osofisan's dramaturgy yields to a multifaceted interpretation and this is witnessed in his presentation of drama as a form of traditional storytelling, and a subsequent Africanisation of his plays. Hence, he claims that Osofisan employs folktales, legend and history, songs music and dance. Specifically, Fatoba (1988) notes that just like a satire, Osofisan, based on his interaction with his society, conceives stories that relate with on-going events in the country basically to correct social ills. From the foregoing, one can reasonably conclude that Osofisan's work are based on on-going events in his society, basically to correct social ills and revolutionary and non-revolutionary in nature.

\section{Literary Pragmatics and Voice}

Literary pragmatics (LP) is all about text production and interpretation. A key issue in literary pragmatics is voice. As earlier mentioned a means to project a writer's worldview is the voice (Mey, 2001). The literal meaning of voice shows that voice is the expression, speech, or utterance of words. Mey (2000) describes voice as a vocalized perspective. These invariably suggest that voice gives expression (vocality) to the inner thoughts of an author as expressed by his characters. It also shows that a character is represented in a narrative by his/her voice. The vividness of this representation usually presents a situation that is close to reality. Bakhtin (1992) observes this when he reveals that the direct way of dialoguing of characters in drama texts appeal to social reality as it is patterned like the structure of everyday conversation which he calls "the dialogic orientation of discourse".

Voice, therefore, enhances the production and interpretation of literary texts. Consequently, Mey (2000) opines that "the determination of voice ownership is central to the understanding of texts". As such, we can conclude that the concept of voice is considered central to literary interpretation. Mey (ibid) notes that voice can be classified into voice shift and voice clash.

Voice shift occurs when there is a transition from the narrator's voice to a character's voice or from a character's voice to another character's voice or from a character's voice to an intruding author's voice (Mey 2000). Voice shift is also known as voice change. In this instance, the author tells his readers that the character whose voice they are listening to has finished his contribution and another one is taking over. This change of voice is achieved through a system of roles which characterizes stage plays.

"Voice clash occurs whenever voices do not match, either the character and a voice that is attributed to that character are out of sync, or two or more of the voices heard in the story are perceived as disharmonious" (Mey 2000: 189). In a narration, characters are expected to be consistent with the role they play and their voices throughout the narrative for the narrative universe that is supposed to be fictitious to be real. In some plays, the narrator too has a voice and in this instance he is also a character in the narrative if in the course of narration therefore the narrator gives counter information, then his voice is said to be disharmonious, consequently, there is voice clash.

Also, Mey (2000) opines that voice clash may be as a result of external factors such as when a character speaks out of turn, that is, when he contributes to the narration when another character ought to. A clash of voice may also occur when a character speaks out of place, that is, when he oversteps his assigned boundaries of narration. Mey (2000) subdivides voice clash into: voice trash, voice mash and voice crash. According to Mey, voice trash is an instance of clashing voices where there is an overlaying voice. In this instance, the voice of the narrator / author totally eclipses the voice of the character. By so doing, the character's world is expressed through the author's voice.

Voices are mashed when they are not clearly distinguished. Mey (2000) reveals that voices here overlap and overlay. There are instances when voices are presumed to continue, but have actually ended at a point, only for the narrator's or the author's voice to continue, as if it is still the character's voice that we are hearing. This more or less confuses the reader, as to him, the point of voice change is not explicitly marked. Voice crash refers to another instance of authorial intrusion. In this voice type, the author intrudes into the narration to reveal important information about the characters, their experiences, and reactions and so on. Although the author speaks through the character, he authoritatively intrudes into the narration and then withdraws for the character or the narrator to continue with the narration.

According to Mey (2001), the voice devices discussed above can be determined in literary texts through the use of textual mechanism such as references, deixis, personal pronouns, tense and so on. These therefore automatically become the pragmatic markers of voices. Thus, for the 
purpose of this study, we define pragmatic markers of voices as those textual mechanisms such as references, deixis, personal pronouns, and tense that enable us to determine voice ownership towards determining authorial perspectives in literary texts.

In making reference, a speaker or writer uses language to enable a listener to identify a person or something (Yule, 1996: 19-20). He observes that the linguistic expression employed here are referring expression which can be proper nouns or noun phrases which are definite, for example; "the author", "the singer", "the island", and so on, or indefinite, such as: "a man", "a woman", "a beautiful place", and pronouns such as: "he", "her", "it", "then", and so on. Yule further observes that speaker's choice of a type of referring expression, rather than the other, depends on what he assumes the listener already knows. However, in shared visual contexts, pronouns functioning as deictics such as "take this", "look at him" are apposite for reference but not in instances where identification (reference) is elaborate, in which case, noun phrases may be employed (Yule 1996). This buttresses the fact that reference is tied to the speaker's goals and his beliefs in the use of language. Consequently, Yule (ibid) concludes that reference is not just a relationship between the meaning of a word or phrase and an object or person in the world, but a social act whereby the speaker beliefs that the word or phrase he has chosen to identify an object or person will be interpreted as he intended.

Mey (2000) observes that "deixis" means the process of showing by means of language that is, "pointing" at things/objects/persons by means of special words. This shows that deixis are pointers (words used like a pointing finger). Mey (ibid) notes that certain pronouns and adverbs (of time and place) are characteristic pointers of deixis. These pronouns and adverbs are employed by a speaker to point to a person or object, either proximal or distal, to the speaker, for example; "this", "here and there", "now and then".

Mey (2000:45) further notes that a particular class referring expressions are located in personal pronoun such as "I", "you", "we" and so on, and their associated adjectival forms like "my", “your", and "our". Yule (1996) also notes that deixis means pointing via language. He observes that deixis is a form of referring that is tied to the speaker's context.

Ogunsiji and Olaniyan (2005: 167) cite examples of personal pronouns such as "I", "we", "me" "she", "her", "it", "you", "they", "then" as personal pronouns that can be classified into three based on persons (first person, second person, third person), and numbers (singular, plural). The importance of personal pronouns, according to Mey (2000), is in their ability to determine a perspective, that is, a speaker's point of view. Knowledge of personal pronouns therefore enables us to determine the lexical choice that has been used to replace or substitute a noun. For example, first person (1st person) denotes the speaker's (narrator's voice, and the second person (2nd person) refers to the addressee, (the person being spoken to).

Verb forms (tenses) are usually marked by a morphological device called tense. It enhances our determination of the point in time of an occurrence. The different voice heard in texts are often recognizable and can be distinguished from one another by reference to their temporal position as indicated by the tense of the verbal expressions used (Mey 2000).

\section{Summary of the Text}

Esu and the Vagabond Minstrels (EATVM) is based on the theme of compassion. In this play, Osofisan creates characters such as Omele, Jigi, Redio, Epo Oyinbo and Sinsin as wandering minstrels. They were in search of what to eat and this took them to the crossroads of Sepeteri. This place is known to be Esu's residence, unknown to the minstrels except Omele who has once been a mechanic apprentice in the locality. The knowledge that they will be eating off foods brought to placate Esu made some of them to be afraid, but Omele and Oga Redio are bent on staying. In the end an old man appeared to them and gives them a magic tip on how to get rich.

The tip given to them involves healing whoever they want to help in exchange for promises of riches. All the other minstrels were greedy and selfish except Omele who showed compassion to two unknown lepers. After healing the lepers, the leprosy came upon him, as he has been warned. The two lepers later turned out to be Orunmila and Yeye Osun. The gods have decided to play a game on the minstrels and in the end Omele was the only one found fit to be called a "human being". Osofisan is therefore telling us to choose the road to take, whether between compassion and greed, between hollow material wealth, and unseen riches of tenderness.

\section{Analysis and Discussion}

Our analysis reveals that Osofisan employs the pragmatic markers of voices such as references, pronouns, deixis, and tenses, through the voice devices of mashing, crashing, and trashing to project issues of power, deviance, and religious belief in the play. These are cursorily examined below:

\subsection{Voices and Issues of Power}

The aspect of power in EATVM is social power. Social power is found in the play to be associated with riches. The Vagabond Minstrels set out to look for the means to change their social status. Most obviously, they desire financial strength, not only to cater for their feeding, but also to make them relevant in the society. Their quest for riches takes them to the old man who empowers them with 
spiritual powers of healing so that will be able to heal people in exchange for riches. Through this, Osofisan emphasizes the extent to which people value riches in the society. Osofisan uses the voice mash device to project social power in the play through personal pronoun, time deixis, anaphoric and exophoric references and past tense form. An instance is found in the play when Man came across the Minstrels after he had been shot. Through Sinsin, we discover that Man must be rich before she heals him. This prompts Osofisan to highlight things that could be achieved with social power as he mashes the vocalization of Man in the example below.

\section{Ex.1 : Sinsin: It doesn't matter. I'II save his life if he's} rich.

Man: (On his knees battling bravely), Rich! What a joke!

So...one of you...none of your know me!

Sinsin: Talk quickly, Are you a rich man?

Man: (Laughing weakly), It must be a joke!

Fate is...is...playing pranks on me

in my dying moments! To think that...that there's

a place in this land where I am unknown, and imbeciles...

imbeciles ask whether I am rich!

Sinsin: So speak! Are you rich or not? Your life hangs on it!

Man: Well...What does it matter! Let me go like this

then unknown, among ignorant fools from some

unknown planet, I have lived a life of fantasy chasing

adventures, daring death itself! I anchored my name

to the winds, so that everywhere, whenever I touched down,

I arrived like fear itself! Yes, when I found that men

had made money their god, I conquered it!.. you know how?

With the blood of virgin children, the sperm of virile men, a

pair of succulent breasts, such as your...(Reaches toward Jigi,

who slaps off his hand).

(EATVM, pgs 49-50).

In example 1, Osofisan reveals the power that the rich wield in our society. As such, people will do anything for anybody that is substantial. Such utterances as, "I have lived a life of fantasy", "daring death itself", "I anchored my name to the winds" and "whenever I touched down, I arrived like fear itself!" aptly reflect social power in the play. Our observation reveals that Osofisan tactically employs personal pronouns to mash reflection of social power. In the utterances identified as reflecting social power, there is a preponderance of the first person singular personal pronoun "I". This is seen in such examples as "I (have lived)", "I (conquered it)", projecting the voice of the author narrating things that can be achieved with social power. Traditional grammar associates the first person personal pronoun with the first speaker, in which case, the speaker in the extract above attempts to tell us about things that are associated with riches. Osofisan could be largely associated with the vocalization of Man here, as deeply considered, Man has reportedly been shot about a hundred times, as such, he ought to be desperate and anxious to get treated. The fact that his agony and shock are expressed when he was told that the hospital in town are closed because the doctors would not work is a clear indicator that Man is in a critical situation. Could this now be the same Man that becomes suddenly boastful as revealed in his expression of satisfaction derived from his attainment of social power?. The foregoing show that the first person singular personal pronoun predominates the boastful voice of Man, which, of course, can only be attributed to the author, Osofisan, since a dying man that had been shot over a hundred times cannot be this satisfied, relaxed and boastful.

The time deixis "whenever (I touched down)" implies "anytime's Man goes anywhere", expresses Man's total control over everything he wants and everywhere he is. It goes back to identify the speaker as the omnipresent homodiegetic narrator who knows the past, present and future and because he creates the textual universe, he is the only one that has total control over issues.

The past forms of tense "have lived", "arrived", and "conquered", are indicators that the acts achieved with social power, as mentioned in the extract, took place in the past. They also locate the speech time to be after the shooting incident. In African society, people place lots of priority on affluence and riches. Special recognition and unlimited regards are given to people in high places. As refracted in Osofisan's textual universe here, the vagabond minstrels are travelling in search of wealth. Their encounter with Man only portrays what an African man will do for wealth. It is such that riches determine a man's status in the society. This, Osofisan aptly presents through an apt manipulation of the voice of Man, thus exhibiting the stance of riches as forming part of the culture of the Post-Colonial African Society.

\subsection{Voices and Issues of Deviance}

The two aspects of deviance found in the play are religious and moral deviances. 


\subsubsection{Voice Devices Associated with Religious Deviance}

The past tense form, place deixes, exophoric reference, and personal pronoun are employed here, through the voice crash device to express these. An instance is found after Jigi has convinced Man not to commit suicide; Man now finds it obligatory to explain the incidence that prompts him to attempt to commit suicide. Let us consider example 2.

Ex.2: Man: Barbaric, isn't it? A pagan custom.

But no one in town will listen to me!

Not even the Christians and Muslims

among us! We call it keeping our traditional customs?

(laugh bitterly). But one day I said no more!

The past must end, so we can clear

the way for the future! Why, other men elsewhere

are sending astronauts to the moon!

We too must march into the future! So I seized

the royal python, symbol of the whole decadence!

I poured petrol on it! I set it on fire! And was I

sorry for the poor thing as it writhed to death!

But well, it died! Yes! The immortal serpent, whom they said could never die, I turned it into ashes.

(EATVM, Pg. 64)

Utterances such as: "I said no more", "I seized the royal python, symbol of the whole decadence!", "I poured on it!", "I set it on fire", "was I sorry for the poor thing, as it writhed to death!", "it died", and "I turned it to ashes are used to project with respect to (religious) sacredness. Man's deviance is obviously manifested in the last sentence of the contribution, "the immortal serpent whom they said could never die, I turned it to ashes". Man, here, is involved in acts that are against the expectations of the society as regards the immortal serpent.

Osofisan successfully achieves this crash through the use of personal pronoun, place deixis and past form of the tense. The first person personal pronoun, as Halliday (1979) reveals, invariably indicates the speaker who narrates from the first person narrative instance. In this situation therefore, we can hear Osofisan's voice through the first person singular personal pronoun which dominates his vocalizations and at the same time indicates the homodiegetic narrative instance. Though, the first person personal pronoun shows Man as being religiously deviant, the voice could pragmatically be linked to Osofisan, as part of the utterances such as "other men elsewhere are sending astronauts to the moon" relates occurrences beyond the experience of Man. The place deixis "elsewhere", referent to such countries as United States, Japan, Germany and so on where astronauts are sent to the moon is also considered beyond the repertoire of the character, as such, it belongs to the author. Such actions as identified in the utterance such as "I seized the royal python", "it writhed to death!", "it died" and "I turned it to ashes" derive through the past form of tense, and these could be said to locate the reference time (R.T.) in the past. This obviously reflects acts of typical post-colonial African men who definitely desires live like every other men "elsewhere". The merit of fabricated textual universe can only be linked to the voice device in this instance.

\subsubsection{Voice Devices Associated with Moral Deviance}

Moral deviance is found in EATVM in situations where individuals act contrary to expected behaviour and use language rather derogatively. When the minstrels are hungry, they start to make a review of their past lives. They see the politicians as living a life of affluence which they would have loved to as well. Such is found in the vocalization of Jigi, (a female and one of the minstrels) whose vocalization Osofisan crashes into to realize this. Let us examine 3 .

Ex. 3: Jigi: (laughing) Ah soldiers! You remember that one,

that night at the police station? He came up to me...

they'd just picked us up at the hotel.....yes, I had just

finished one of my numbers, and the audience was

claping, when-suddenly, soldiers

everywhere!...

The stampede, ah! So, at the station, where they took us,

the man said to me: "why don't you go and farm" why

waste your life away in the corruption of the city?"

That's what he called it, corruption! (Hisses). Well,

I told him. I said, "soldier, what do you mean? How

can I go and farm, when I myself, I am a farm already?"

He was puzzled by that. You should see his face.

"I beg your pardon?" he asked. "You don't understand?

No? well, its like this...the man brings his shovel to

where I am lying. He digs. Yes, he digs! And respond, 
like this! (makes a suggestive movement with her

buttocks). Soldier, don't turn away. Let me tell you...

how the seeds pour in!".

(EATVM Pg. 27)

All along in the play, the vocalization and trend of events are expressed in the present form of tenses. However, Jigi's vocalization above is a flashback on events, occasioned by the expression, "you remember". Osofisan finds this point convenient to intrude and pass comments on the earlier view of Oga Redio about government's call for people to "go and farm!". His comments link the citizens with the corruption in the city rather than the government. One could hear Jigi's voice through the utterance "Ah, Soldiers!" where it stopped for Osofisan to begin his narration from "you remember that one" till the end of the vocalization. In this situation, Osofisan feels the need to explain and give more information about the state of decadence in his community. Thus, Osofisan pragmatically projects the theme of moral deviance as one of the causes of the decadence in the society.

Such utterances as "I told him, I said", "how can I go and farm, when I myself, I am a farm already?", "he was puzzled by that, you should see his face", "I beg your pardon", "he asked", "you don't understand?", "no well, it's like this...the man brings his shovel to where I am lying", "he digs", "yes he digs", "I respond like this!", "soldier don't turn away. Let me tell you how the seeds pour in!" are indicators of moral deviance employed in EATVM through voice crash.

A close observation reveals that the expressions are largely dominated by first person singular personal pronouns signifying the homodiegetic (first person) narrative instance while there are aspects of the discourse that could also be ascribed to the third person singular personal pronoun, "he" indicating a narration from the heterodiegetic (third person) narrative instance. In the excerpt therefore, Osofisan combines the two forms of narration to intrude into the vocalization of Jigi from "why don't you go and farm" to the end of the vocalization. Jigi, as presented in the play, is not too intelligent to pun on the word "farm", hence, the realization of the shift in the form of the vocalization from the question "why don't you go and farm?'

The intelligence of Osofisan also overshadows that of Jigi through the homodiegetic narration as revealed in "the man brought his shovel" (indicating the man's manhood), "to where I am lying", (indicating a woman's assumption of mating position). The heterodiegetic narrator took over through the third person singular personal pronoun as in "he digs" (that is, he "makes love" to her), and followed the homodiegetic narrator with the first person singular pronoun "I" in "I respond like this". Obviously, the pun on words is beyond the experience of Jigi.

\subsection{Voices and Issues of Belief}

\subsubsection{Religious Belief is the Only Aspect of Belief Found in the Play}

Religious belief is projected in terms of people's faith in certain spiritual beings as having the capability to meet their needs. Through the voice trash device, Osofisan uses person deixis, place deixis, and past tense form to deal with the issue of faith. When the minstrels go to Sepeteri in search for food, they panic when they learnt that they are going to share Esu's food with him. Having been convinced to stay, Osofisan relates why and how the food gets to Esu. This is reflected in 4 below:

Ex 4: Omele: As offering to Esu from those looking for children

or for riches, or for a long life. You see Sepeteri

is the last point between the town behind

us and the sacred grove of Orunmila over there.

So, Esu, the lord of Sepeteri is regarded as a kind of intermediary, between man and their wishes, between destiny and fulfillment.

If you wait in a short while you will see they will soon begin to arrive with their baskets and pots to placate Esu, the whole place will be laden with food!

(EATVM, Pg. 23)

In example 4, we can hear Omele's voice from "as offering to Esu" to "for a long life". Osofisan intrudes into the narration from "you see" till the end of the vocalization. Through person deixis "you", Osofisan tactically intrudes into the vocalization of Omele. A further consideration of the utterances suggests that the minstrels are new in the area and cannot quite understand issues relating to Esu and the worship of Esu. Osofisan skillfully introduces Omele into the scene as having stayed in the area as a mechanic apprentice previously. But Osofisan's voice is betrayed by the fact that a mere mechanic apprentice that is said not to be serious minded could not be intelligent enough to describe Sepeteri and employ such register as "sacred grove" for the point where Orunmila is worshipped. Osofisan's voice trashes that of Omele here as his voice overshadows that of Omele. This is further established by the fact that Omele's experience is expressed through the voice of Osofisan. Through voice trash, therefore, Osofisan projects the issue of faith in the context of religious belief in EATVM.

He further delves into the details of the people's faith in Esu. Through the past tense form, Esu, the lord of Sepeteri is, "regarded" (as a kind of intermediary, between men and their wishes, between destiny and fulfillment)s, Osofisan 
reveals the faith of the people in Esu. Omele could not have been syntactically competent to employ such lexical choices to express the position of the people about Esu. The utterances establishes that the people regard Esu as a kind of intermediary between "men and their wishes", between "destiny and fulfillment". Such lexical choices are considered to be beyond the knowledge and experience of an ordinary mechanic apprentice.

Instances of person deixis, place deixis, and spatial deixis are variously employed here as reflected in the foregoing: "you see, Sepeteri is the last point between the town behind us and the sacred grove of Orunmila there", "if "you" wait in a short while", and "they" will soon begin to arrive with their baskets and pots to placate Esu". These demonstrate the vocalization of a character that stands in the position of a narrator. Through the person deixes, Osofisan intrudes into the vocalization to narrate the facts about Sepeteri, and how close Esu's shrine is to Orunmila's grove. The fact that the owner of the voice here is confident that the worshippers, represented by "they will soon begin to arrive", and that he knows how they characteristically come to worship Esu (with their baskets and pots), reveals trashing of voice. Omele as a mechanic apprentice, who have left the area for quite some time could not have known these facts about Esu and his worshippers. The place deixis "the grove of Orunmila over there" shows the narrator's intention to create the impression of the closeness of "Esu" to "Orunmila". It is only Osofisan that can reveal such, so as to erase the belief from certain quarters that Esu is evil. The Yoruba belief is that Orunmila is good. Anywhere that Orunmila (the father of Ifa) is, Esu is always located close to him. This signifies that Orunmila and Esu are close friends. If Esu is evil, Orunmila cannot be close to him. Osofisan exploits this phenomenon therefore, to project Esu as being good thereby promoting African traditional culture that seems to be forgotten.

\section{Conclusions}

Through the pragmatic markers of pronoun forms, person, time, and place deixes, anaphoric references, past tense forms of voices, and references, we are able to determine how Osofisan employs the voice devices of voice mash, voice trash, and voice crash, to project his perspectives on issues of social power, moral and religious deviances, and religious beliefs in EATVM. This justifies the belief that Osofisan usually vocalizes his perspectives through his narrators thereby trashing, mashing or crashing into the vocalization of his characters. The devices largely portray the stance of post-colonial Africa relative to issues of culture and society. The study therefore enhances our ability to use the pragmatic markers of voices to determine voice ownership and Osofisan's thematic preoccupations in his play EATVM. The application of pragmatic markers of voices is expected to be helpful in in this direction when applied to other African culture-based literary text.

\section{REFERENCES}

[1] Adeniji Adeolu. "Pragmatics of Voices in Femi Osofisan's Non-Revolutionary Plays", M. Phil Dissertation, University of Ibadan, Ibadan, 2009.

[2] Adeniji, Adeolu and Osunbade. 'Niyi "Pragmatic Functions of Tradition-motivated Discourses in Ahmed Yerima's Ajagunmale" International Journal of English Language and Literature Research, 2, (2), 2014. 1-14. (UK).

[3] Awodiya, M. "Excursions in Drama and Literature: Interview with Femi Osofisan", Ibadan: Kraft Books Limited, 1993.

[4] Awodiya, M. "The Drama of Femi Osofisan: A Critical Perspective", Ibadan: Kraft Books Limited 1995.

[5] Bakitin, Mikhail M. "Discourse in the Novel" (Caryl Emerson and Michael Holquist, Trans). The Dialoguic Imagination: Four Essays by M. M. Bakhtin. Ed. Holquist M. The University of Texas Press, Austin. 1992. 259-422.

[6] Dasylva, A. O. "Studies in Drama" Ibadan: Sam Bookman Educational and Communication Services, 2004.

[7] Egbarevba, C. "Humanistic Vision in Femi Osofisan's Drama" Journal of Nigerian English and Literature. Jonel 1. 2000:28-53.

[8] Fatoba F. "A critical Analysis of Femi Osofisan's Play" An Unpublished Ph.D Thesis: Department of Theatre Arts, University of Ibadan, 1988.

[9] Mey, Jacob, L. “When Voices Clash" Mouton de Gruyter, Berlin; New York, 2000.

[10] Mey, Jacob, L. "Pragmatics: An Introduction" $2^{\text {nd }}$ Edition Blackwell, Malden, Mass and Oxford, 2001.

[11] Obafemi O. "Contemporary Nigeria Theatre: Cultural Heritage and Social Vision" Bayreuth: Bayreuth African Studies, 1996.

[12] Osofisan, Femi. "Esu and the Vagabond Minstrels". Ibadan: New Horn Press Ltd, 1991.

[13] Richards, S. "Ancient Songs Sets Ablaze: The Theatre of Femi Osofisan" Washington: Howard University Press, 1996. 